\title{
The Impact of Non-Farm Income on the Incidence of Poverty among Farmers in Kedah, Malaysia
}

\author{
Siti Hadijah Che-Mat, Nor’ Aznin Abu Bakar, and Ahmad Zafarullah Abdul Jalil
}

\begin{abstract}
The objective of this paper is to analyse the impact of non farm income on the incidence of poverty in Kedah. The data used in this study is primary data which is gathered through a survey carried out among agricultural households in Kedah Darul Aman, Malaysia. A total of 384 agricultural households participated in this survey. A face to face interview was carried out with selected respondents between the month of April and December 2008. To study the effect of non-farm income to the level of poverty, this study used a FGT index as proposed by Foster-Greer-Thorbecke (1984). This study finds that about 32 percent of the household have non farm activities and non farm income reduce the level, depth and severity of poverty in Kedah. Non farm income has a greater impact on reducing the severity as opposed to the level and depth poverty in Kedah. The study showed non-farm income reduces the poverty rate of $42.94 \%$, while poverty declined by $51.47 \%$ and the squared poverty gap- which measures the severity of poverty- fall by 55.72 percent when non farm income are included in household income. On the other hand the severity of poverty fall by 23.35 percent when transfer payment are included in such income. This is true because agricultural households receive a very large share of their total household income from non farm income compared to transfer payment.
\end{abstract}

Index Terms-Kedah, Poverty, Malaysia, non-Farm Income.

\section{INTRODUCTION}

In the past, many researcher and policymaker have viewed the rural economy of developing countries as being synonymous with agriculture. Most of these poor households are usually agricultural workers and small farmers, where agricultural activities usually represent their main source of income. However, with the rapid growth and the structural changes experienced by the Malaysian economy during these last few decades, has resulted in declining share of agriculture sector in output and employment. The reliance of the Malaysian economy in terms of output and employment now shifted from agriculture to industrial and services sectors. Consequently, the rural economy changes too. Rural industrialisation programmes, improvement in rural infrastructure and transportation, as well as other rural development programmes undertaken by the government to develop the rural areas may have directly or indirectly open up the opportunities for non-farm employment.

Manuscript received July 6, 2011; revised August 1, 2011.

Siti Hadijah Che-Mat, Senior Lecturer at Department Of Economic, Finance and Banking, College Of Business, Universiti Utara Malaysia, 06010, Sintok, Kedah, Malaysia; Corresponding emailhadijah@uum.edu.my

Nor' Aznin Abu Bakar, Associate Professor, at Department Of Economic, Finance and Banking, College Of Business, Universiti Utara Malaysia, 06010, Sintok, Kedah, Malaysia.

Ahmad Zafarullah Abdul Jalil, Senior Lecturer, at Department Of Economic, Finance and Banking, College Of Business, Universiti Utara Malaysia, 06010, Sintok, Kedah, Malaysia
As a consequent, the arising of opportunities for diversification of income sources of rural households might have also changed the structure of rural household income and might have significant consequences on poverty. In fact, it has been widely perceived that promoting the development of the non-farm sector and hence, encouraging farmers to diversify their income sources is desirable, since it is perceived that this will help increase their income and hence reducing rural poverty. While it seems that encouraging farmers to diversify their income sources is desirable, its impact on poverty remains to be substantiated. In fact, there are reasons to believe that promoting the non-farm sector, and encouraging farmers to participate in non-farm employment, might reduce poverty. The question now is, how much in term of percentage the poverty will reduce if the agricultural household involve in non-farm activities. Understanding this question, i.e. the impact of non-farm employment on poverty, could shed lights on this issue and perhaps could guide policy makers in designing appropriate strategy for rural development. The empirical evidence on this question is provided by estimating a FGT index using primary data gathered from agricultural household in Kedah, Malaysia.

\section{LITERATURE REVIEW}

Studies have shown that non-farm income increasingly plays an important role and exhibits an increasing share in agricultural household income (De Janvry et.al, 2005; FAO, 1988). Thus, the non-farm (or off-farm) employment has been generally recognised to have the potential in raising agricultural household income, and therefore reducing rural poverty (FAO, 1998; Arif, Nazli and Haq, 2000; Lanjouw and Murgai, 2008; Foster and Rosenzweig, 2004). Non-farm income gradually became an importance source of income for rural households, and served as an engine of growth for rural areas In fact, Ranjan (2006) has pointed out several grounds on the desirability of developing the non-farm sector as a vehicle to reduce rural poverty. Among them are: (i) the growing rural communities cannot be sustained by the agricultural sector alone; (ii) rural economies are not purely agricultural and most of the rural communities derive their incomes from various sources rather than from agriculture per se; (iii) avoid rural-urban migration; (iv) reduce the rural-urban economic disparities; (v) reduce rural unemployment since rural industries are usually labour-intensive and hence, expected to absorb more labour; (vi) intensifies lingkages between industry and agriculture, and thus support agricultural growth; (vii) reduce income inequality in the rural areas since the lower income group is expected to participate more intensely in non-farm activities; and (viii) encourage the participation of women in the 
non-farm sectors and hence empowering them. Adams (2001) on his study at Egypt and Jordan, find that non-farm income has a greater impact on poverty and inequality. The poor receive almost 60 percent of their income from non-farm sources in rural Egypt, while in rural Jordan they receive less than 20 percent.

Lanjouw (2000), proved through the study of households in the state of Ecuador on the role played by non- farm sector to poverty reduction in rural areas. The results showed the state's non-farm sector contributed $40 \%$ of rural incomes. Nearly $40 \%$ of men and $50 \%$ of the women involved in this activity and also income from non-farm employment is associated positively with the level of education and infrastructure.

De Janvry (1981), wages from a part time job in rural areas often complement the inadequacy of agricultural production to ensure the needs of household consumption will continue to be enjoyed. De Janvry et al. (2005), studies in China, involving 7041 households with agricultural and non agricultural income showed, $72 \%$ of rural households have non-farm income. Non-farm income is not only able to absorb surplus labor in rural areas, but more importantly what it can improve is the quality of life in rural areas. It can be concluded that non-farm income can be considered as a potential successor to the agricultural income. His study also found that the factors of education, close to town, the influence of neighbors and the influence of residential area, is crucial in helping particular households gain the opportunity to diversify its economic activities. A study done by Roslan and Siti Hadijah (2011), found that farmers that participate in non-farm activities, has a clearly shorter their average time to exit poverty than those who did not participate in non-farm activities. In this study we go a step further by investigating to what extent poverty can be reduced when farmer have non-farm activities together with his/her agricultural household income.

\section{DATA AND METHODOLOGY}

The state of Kedah was chosen because there are many people involved as a farmers compared to the states in Peninsular Malaysia. Kedah also have highest poverty rate in Peninsular Malaysia. For example in 2004, Kedah recorded a high overall poverty level of 7\% (27.300 households). Poverty is above the overall poverty rate of $5.7 \%$. (UNDP, 2004 and Malaysia, 2006). Agriculture is one of the main economic sector in the northern states, particularly in Kedah. According to the UNDP report of 2004 and the 9th Malaysia Plan (2006), the workforce engaged in agriculture in the Northern Territory Malaysia by state is $21.7 \%$ of the workforce in Perlis, Kedah 19\%, 18\% Perak and 1.4\% on the Island Penang.

\section{The data and sample}

The data used in this study is primary data which is gathered through a survey carried out on 384 agricultural households in the state of Kedah, Malaysia. The survey is conducted between the month of April and December 2008. A face to face interview were carried out with the respondents, where they were chosen through a stratified random sampling. Six of the eleven districts in Kedah were chosen in this study. These are Kubang Pasu, Sik, Kota Star, Baling, Kulim dan Pulau Langkawi. Table 1 shows the number of respondents by district.

TABLE I: RESPONDENTS BY DISTRICT

\begin{tabular}{lcc} 
District & $\begin{array}{c}\text { Estimated agricultural } \\
\text { households }\end{array}$ & $\begin{array}{c}\text { Number of } \\
\text { respondents }\end{array}$ \\
\hline Kubang pasu & 8,736 & 71 \\
Kota Star & 16,541 & 135 \\
Baling & 5,913 & 48 \\
Kulim & 9,455 & 77 \\
Pulau Langkawi & 3,541 & 29 \\
Sik & 2880 & 23 \\
\hline Total & $\mathbf{4 7 , 0 6 7}$ & $\mathbf{3 8 4}$ \\
\hline \hline
\end{tabular}

Source: Population and Family Development Board (2004)

For each district, the respondent is divided further according to the local economic characteristics (economic structure of the local economy), to see the importance and strength of the existence of industry and agriculture to the farmers to engage in non-farm activities. The involvement of farmers in non-farm activities is expected to increase household incomes and reduce poverty. The economic characteristics of the region are as follows:

1. $($ TTIT $=\mathrm{C} 1)=$ Refers to the farmers who are in locations or areas with high intensity in agricultural activities and have high intensity in terms of industrial existence.

2. $(\mathrm{TTIR}=\mathrm{C} 2)=$ Refers to the farmers who are in locations or areas with high intensity in agricultural activities but with low intensity in terms of industrial existence.

3. $($ TRIR $=\mathrm{C} 3)=$ Refers to the farmers who are in locations or areas with low intensity in terms agricultural activities and low intensity in terms of industrial existence.

4. $(\mathrm{TRIT}=\mathrm{C} 4)=$ Refers to the farmers who are in locations or areas with low intensity in terms of agricultural activities, but have high intensity in terms of industrial existence.

(Note: $T$ refers to agriculture; I, refers to industrial R, referring to the low $\mathrm{T}$, referring to high. )

The survey was comprehensive, collecting detail information on a wide range of topics, including income from agricultural activities, income from other economic activities, unearned income, education, expenditure and time their spent on agricultural activities as well as on non-farm activities. But in this paper, we just used the information on income receive by the agricultural household. In this paper we also divide the total income receive by the household in to three separate item, one is for agricultural income, second is income from non-farm activities and the third one is unearned income (transfer payment). With regards to the income from non-farm activity, in this paper we refer income from non-farm activity as the income receive by agricultural household in remunerative work away from their plot of agricultural land (FAO, 1988). The non-farm job undertaken by the farmer could be permanent or casual in nature, covering both the secondary and tertiary sector of employment (Salter, 1991). Besides, to disaggregate the poor from the non-poor, poverty line income is used. The official gross poverty line income for the state of Kedah in 2009 is RM7001. Thus, in this study, a farmer with a household income that is equal or more than RM700 is considered

${ }^{1}$ e-SINAR.Kedah.gov.my 
non-poor, while those with household income that is less than RM700 is categorised as poor.

In this paper we calculate the agricultural household income for 381 excluding non farm income and unearned income (transfer payment). The results from these calculation can then be used as a basis for evaluating the impact of non-farm income and unearned income on poverty when non-farm income and unearned income (transfer payment) are included in agricultural household income.

FGT index is used in this study. With the modification of this index, according to Foster-Greer-Thorbecke (1984) it can be used to observe the effects of non-agricultural income on poverty. As Huppi and Ravallion (1991) used this index to see the effect of sources of income on poverty in Indonesia. While Reardon and Taylor (1996) make the separation on the FGT poverty, according to sources of income. FGT indices allow us to see the index for each group (perhaps through the area, or income level) among the poor.

Following is the method used by Adams (2004) in his study of poverty in Guatemala. This study will follow the Foster-Greere-Thorbecke (hereafter FGT) poverty index (1984) to measure the index of poverty for agricultural household as Adams (2004). The FGT poverty measure is defined as:

$$
P_{\alpha}=\frac{1}{n} \sum_{i=1}^{m}\left(\frac{z-y_{i}}{z}\right)^{\alpha}
$$

where $\mathrm{n}$ is the whole sample used in this study, $\mathrm{m}$ is the total number of households living under the poverty line, yi is represents the income of the poor household from $\mathrm{i}$ to $\mathrm{m}$ which arrange in increasingly order, $\mathrm{z}$ is the poverty line income and $\alpha$ is a poverty aversion parameter. The three parameter (depending on three values of $\alpha$ ) of the poverty index used to estimate the impact of changes in non-farm income and unearned income on poverty are: the headcount ratio index $(\alpha=0)$ which is measure the share of population living below the poverty line; the poverty gap index $(\alpha=1)$ to measures the depth of poverty, that is the amount by which an average poor family is below the poverty line. The poverty gap squared index $(\alpha=2)$ to measures the severity of poverty and, unlike the other two measures, is sensitive to changes in the distribution of income among the poor (Adams and Page 2005). It satisfies the important "transfer axiom" for a desirable poverty measure which requires that "given other things, a pure transfer of income from a person below the poverty line to anyone who is richer must increase the poverty measure" (Sen 1976).

In this study, income of the household are divided into four groups, as done by Adams (2004). The first group is the farmer who have only agricultural income. The second group is income from agricultural income plus non-farm income, the third group is income receive by farmer from agricultural activities and unearned income and the last group is total income receive by farmer.

In this way the calculation of the increase or the difference in any one income group can be obtained when comparing the second, third and fourth group with the first group.

\section{FINDINGS}

There are two results will be discussed in this section. The first one is about the poverty rate by four economics characteristic using FGT index and the second one is the contributions of each sources of income to poverty level. Table 2, summarizes the sources of income receive by households. The table shows clearly the importance of non-agricultural sources of income other than agricultural income. Agricultural income shows that the most important source of income with a total of 62.21 per cent to total income. Non-farm income also contributed to the increase in total income. A total of 32.35 per cent of income comes from non-farm activities. While only 5.44 per cent of unearned income. The average income received by households regardless of non-farm income and unearned income is RM 1310.29. However, after taking into account the income receive from non-farm sources of income, the average income increase about RM681.34 to become an average income of RM1, 991.63. This means that non-farm income could make the average income of farmers increased.

TABLE II: SOURCES OF INCOME

\begin{tabular}{ccc}
\hline \hline \multicolumn{1}{c}{ Sources of Income } & $\begin{array}{c}\text { Average } \\
\text { Income Per } \\
\text { Month (RM) }\end{array}$ & \% income \\
\hline Agricultural Income (Farminc) & $1,310.29$ & 62.21 \\
Non-farm (Ofarminc) & 681.34 & 32.35 \\
Unearned income (Transinc) & 114.66 & 5.44 \\
\hline Total Income (Totalinc) & $2,106.29$ & $\mathbf{1 0 0 . 0 0}$ \\
\hline \hline $\mathrm{n}=381$ & &
\end{tabular}

Poverty by Economic Area / Location.

By using FGT indices, the three index values can be obtained simultaneously and a more comprehensive comparison can be done.

TABLE III. POVERTY RATE BY ECONOMIC AREA USING FGT INDEX MEASUREMENT (RM-PGK700).

\begin{tabular}{lcccc}
\hline \hline Location & $\begin{array}{c}\text { Farmer with } \\
\text { NFi }\end{array}$ & $\alpha=0$ & $\alpha=1$ & $\alpha=2$ \\
\hline $\mathrm{C}_{1}(87)$ & $37(0.4253)$ & 0.1264 & 0.0270 & 0.0124 \\
$\mathrm{C}_{2}(133)$ & $45(0.3383)$ & 0.1654 & 0.0526 & 0.0287 \\
$\mathrm{C}_{3}(79)$ & $11(0.1392)$ & 0.4177 & 0.0483 & 0.0202 \\
$\mathrm{C}_{4}(82)$ & $30(0.3658)$ & 0.0488 & 0.0115 & 0.0043 \\
\hline $\operatorname{Tot}(381)$ & $122(0.3658)$ & 0.1811 & 0.0663 & 0.0344
\end{tabular}

Note: $\mathrm{C}_{1}$ to $\mathrm{C}_{4}$, referring to the definition of the area/location as mention in methodology of the study. Figures in parentheses (location) are actual number of farmers who are below poverty line

Table 3 shows the poverty index for the four features of the area / location using the poverty line income (PLI) RM700.00. The results showed the features of the $\mathrm{C} 4$, which have the intensity in the industrial and less intensity in agricultural activities shows the lowest poverty index compared with the characteristics of other areas. In areas characterized by $\mathrm{C} 4$, with respect to $\alpha=2$, the lowest poverty index was 0.0043 compared to the $\mathrm{C} 2$, which is 0.0287 . As a conclusion, even using a different method of calculation, poverty still shows among the lowest in areas with high intensity in industry in $($ TTIT $=\mathrm{C} 1)$ and $($ TRIT $=\mathrm{C} 4)$, compared with the area with low intensity in terms agricultural activities and low intensity in terms of industrial existence (TRIR $=\mathrm{C} 3)$.

Table 4, report three different poverty measures based on poverty line income for Kedah in the year 2010 which is RM700 per household. This poverty line is used to differentiate the poor from the non poor in Kedah. If a 
household earns an income of RM700 and above, it is considered as not poor but if household earns less than RM700, it is categorised as poor. The poverty headcount index is measure the percent of the population living below the poverty line. However, this headcount index ignores the depth of poverty, that is the amount by which the average expenditure of the poor short fall of the poverty line. The table therefore also reports the poverty gap index, which measures in percentage terms how far the average expenditures of the poor short fall of the poverty line income. The third poverty measure is the squared poverty gap index. This index indicates the severity of poverty. The squared poverty gap index possesses useful analytical properties, because it is sensitive to changes in distribution among the poor. In other words, while a transfer of expenditure from a poor person to a poorer person will not change the headcount index or poverty gap index, but it will decrease the squared poverty gap index.

Columns (1-4) in Table 4 report results for the different poverty measures. Column (1) report results in the excluding non-farm income and unearned income. Column (2) reports results when only non-farm income are included in household agricultural income. Column (3) reports the results when only unearned income are included in the household agricultural income. Column (4) reports results when both non-farm income and unearned income are included in household income.

All of the poverty measures show that the inclusion of non-farm income and unearned income into the agricultural household income reduce the level, depth and severity of poverty in Kedah. However the size of the poverty reduction depends very much on how poverty is measured. According poverty headcount measure, including non-farm income to income agricultural household reduces the level of poverty by 42.94 percent and inducing unearned income in agricultural household income reduces the level of poverty by 14.72 percent. However, poverty is reduced much more when measured by indicators focusing on the depth and severity of poverty, such as the poverty gap and squared poverty gap. For example, the squared poverty gap measure shows that including non farm income and un earn income in household agricultural income reduce poverty by 55.71 or 23.35 percent, respectively. In other words, including non farm income and unearned income in agricultural households income, has greater impact on reducing the severity of poverty in Kedah than it does on reducing the proportion of people living in poverty.

With respect to poverty, this table shows that non-farm income has a slightly greater impact on poverty than unearned income. For instance, all three poverty measures shows that the extent of poverty reduction is greater when non-farm income are included in agricultural household income, as opposed to when unearned income are included. When both non-farm income and unearned income are included in agricultural household income, the effect on the poverty reduction is high. The reduction in head count ratio, depth of poverty and squared poverty gap index are 55.76 percent, 63.27 percent and 66.67 percent respectively.

TABLE 4: FGT INDEX: EFFECT OF NON-FARM INCOME ON POVERTY, KEDAH

\begin{tabular}{|c|c|c|c|c|c|c|c|c|}
\hline \multirow[t]{3}{*}{ PLI/ $\alpha$} & & $\begin{array}{c}\text { Farm } \\
\text { income only }\end{array}$ & $\begin{array}{l}\text { Farm income } \\
\text { and Non farm } \\
\text { income only }\end{array}$ & $\begin{array}{l}\text { Farm income } \\
\text { and un earn } \\
\text { income only }\end{array}$ & $\begin{array}{l}\text { Total house hold } \\
\text { income }\end{array}$ & $\begin{array}{c}\text { \% Change } \\
\text { (Farminc vs. ada } \\
\text { NFi) }\end{array}$ & $\begin{array}{c}\text { \% Change } \\
\text { ( Farminc vs. } \\
\text { Transinc) }\end{array}$ & $\begin{array}{l}\% \text { Change } \\
\text { (Farminc vs NF } \\
\text { dan Transinc) }\end{array}$ \\
\hline & & $\stackrel{@}{\text { Farminc }}$ & $\stackrel{a}{\text { Farminc + NFi }}$ & $\begin{array}{c}\text { Farminc + } \\
\text { Transinc }\end{array}$ & $\begin{array}{c}\text { Farminc + NFi+ } \\
\text { Transinc }\end{array}$ & {$[(2)-(1)] /(1)^{*} 100$} & $\begin{array}{c}{[(3)-(1)] /(1)^{*}} \\
100\end{array}$ & $\begin{array}{c}{[(4)-(1)] /(1)^{*}} \\
100\end{array}$ \\
\hline & & (1) & (2) & (3) & (4) & (5) & (6) & (7) \\
\hline \multirow[t]{3}{*}{700} & 0 & 0.4094 & 0.2336 & 0.3491 & 0.1811 & -42.9409 & -14.7289 & 55.7645 \\
\hline & 1 & 0.1805 & 0.0876 & 0.1456 & 0.0663 & -51.4681 & -19.3352 & -63.2687 \\
\hline & 2 & 0.1032 & 0.0457 & 0.0791 & 0.0344 & -55.7171 & -23.3527 & -66.6667 \\
\hline
\end{tabular}

Note: Column (1) measure the situation for 381 agricultural household income. Column (2) measure the situation for all households when only non farm income are included in the agricultural household income. Column (3) measures the situation for all households when only un earn income are included in the agricultural household income. Column (4) measures the situation for all households when both non farm income and un earn income are included in the agricultural household income. Poverty calculation made using poverty line income by the State of Kedah in 2010, it is RM700.00. Column (5) (6) and (7) are poverty calculation in term of percentage change gathered through comparison between the column (2) (3) and (4) to the column (1) and multiple by 100. NFi is non-farm income, Transinc is same as Unearned income that is income receive from other sources like remittances, zakat, pension, and ect. Farminc is agricultural income.

\section{CONCLUSIONS}

The main objective of this paper is to analyze the impact of the inclusion of non-farm income and unearned income on the level, depth and severity of poverty among farmers. The results seem to indicate that the inclusion of non-farm income has a higher impact on poverty reduction as compared to unearned income. The severity of poverty falls by 55.72 percent when non farm income is included in household income. Meanwhile, the same indicator falls by only 23.35 percent when transfer payment is included in such income.

The findings of this study imply that non-farm activities are one of the options that should be given more emphasis by the relevant authorities in the crafting of poverty eradication programs among farmers. These authorities should look into measures that will enable more poor farmers to participate effectively in non-farm activities. They should also look into the factors that are inhibiting some farmers from participating in non-farm activities and assistance should be given to these farmers accordingly. However, it should be noted that not all non-farm activities are similar in term of their effectiveness in reducing poverty among farmers. Issues such as cost-effectiveness of the non-farm activities, technical know-how and readiness of the farmers and resources requirement should be taken into consideration when it comes to measure the effectiveness of non-farm activities.

\section{REFERENCES}

[1] A.H.Roslan and C.M.Siti Hadijah, "Non-Farm Activities and Time to Exit Poverty: A Case Study in Kedah, Malaysia," World Review of Business Research, vol. 1, pp. 113-124, Mei 2011. 
[2] Adams R.H \& Page, "Do International Migration and Remittances Reduce Poverty in Developing Countries?,"World Development, vol. 33, No.10, pp. 1645-1669, 2005.

[3] Adams,R.H, ".Nonfarm income, inequality and poverty in rural Egypt and Jordan," Policy research working paper WPS2571, 2001.

[4] Arif, G. M., Nazli, H. \& Haq. R, "Rural non-agriculture employment and poverty in Pakistan," The Pakistan Development Review, 39(4), Part II, pp. 1089-1110, 2000.

[5] De Janvry, A., Sadoulet, E., \& Zhu, N, "The role of non-farm income in reducing rural poverty and inequality in China," Department of Agricultural \& Resource Economics, UC Berkeley. Working Paper No $1001,2005$.

[6] De Janvry, Alain, The agrarian question and reformism in Latin America, Baltimore, John Hopkins University Press, 1981.

[7] FAO, Rural non-farm income in developing countries. The State of Food and Agriculture, 1998. Available:

http://www.fao.org/docrep/w9500e/w9500e12.htm\#12-22

[8] Foster, J., Greer, J. \& Thorbecke, E, "A class of decomposable poverty measures," Econometrica, 52(3), pp. 761-766, 1984.

[9] http://esinar.kedah.gov.my/WEBe-SINAR/main.cfm?content=11. access $11 / 5 / 2009$

[10] Lanjouw, P, "Rural non-agricultural employment and poverty in Latin America: evidence from Ecuador and El Salvador," In López R. and A. Valdés (eds.). Rural poverty in Latin America. London: Macmillan Press, 2000.

[11] Lanjouw, P. \& R. Murgai, "Poverty Decline, Agricultural Wages, and Non-Farm Employment in Rural India 1983-2004," Washington DC: The World Bank Policy Research Working Paper 4858, March 2008
[12] Ranjan, S, "Occupational Diversification And Access To Rural Employment: Revisiting the Non Farm Employment Debate," MPRA Paper 7870, University Library of Munich, Germany., 2006,

[13] Ravallion, M and Huppi, M, "Measuring changes in poverty: A methodological case study of Indonesia during an adjustment period," World Bank Economic Review, vol.5, pp. 57-82, 1991.

[14] Sen, A, "Poverty: An Ordinal Approach to Measurement," Econometrica, 44, pp. 219-231, 1976.

[15] Slater, R, From farm to firm: rural diversification in the Asian Countryside, Aldershot: Avebury Academic Publishing Group,1991.

[16] UNDP, "Malaysia measuring and monitoring poverty and inequality" Economic Planning Unit, Jabatan Perdana Menteri, 2007.

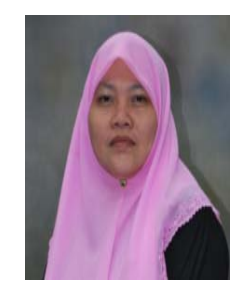

Siti Hadijah Che Mat was born in Melacca, Malaysia on $2^{\text {nd }}$ January 1972 . She got her Master degree on Economic Development at University Putra Malaysia in 1998 and her $\mathrm{PhD}$ on Economic at Universiti Utara Malaysia in 2010. To be specific her $\mathrm{PhD}$ study more on farm and non-farm income and it relationship on poverty and inequality income.

She worked as a LECTURER since 1998 at Universiti Utara Malaysia until now. As a senior lecturer, she publish a list of books and article on her field. For example, Non-Farm Activities and Time to Exit Poverty: A Case Study in Kedah, Malaysia; Non-Farm Income and Poverty in Kedah, Malaysia; The Effects of Non-Farm Income on Poverty: A Case Study on Farmer in Kedah. 